\title{
Detection of Brucella melitensis DNA in the milk of sheep after abortion by PCR assay\#
}

\author{
Detección de ADN de Brucella melitensis mediante la prueba de PCR \\ en muestras de leche de ovejas postaborto \\ Z Ilhan*, H Solmaz, A Aksakal, T Gulhan, IH Ekin, B Boynukara \\ University of Yüzüncü Y1l, Faculty of Veterinary Science, Department of Microbiology, 65080 Van, Turkey
}

\begin{abstract}
RESUMEN
El diagnóstico de laboratorio de brucelosis es generalmente realizado por métodos microbiológicos y serológicos. La prueba PCR es reconocida como una alternativa específica y sensible para la detección de diferentes agentes bacterianos. Se realizó una evaluación de la prueba PCR para la detección de ADN de Brucella melitensis en leche de oveja. Ciento dos muestras tomadas de ovejas postaborto fueron analizadas por métodos de cultivo bacteriológico, prueba PCR y prueba del anillo en leche (MRT). El PCR detectó ADN de B. melitensis en 24 (23,5\%) de 102 muestras de leche, mientras que solamente $8(7,8 \%)$ muestras de leche fueron positivas a B. melitensis por cultivo directo. El MRT detectó $28(27,4 \%)$ muestras positivas de leche.

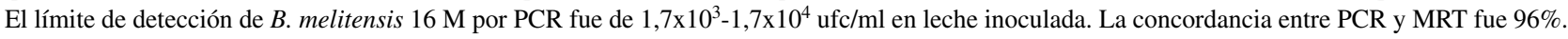
La sensibilidad diagnóstica y la precisión fueron determinadas como el $100 \%$ y el $81,3 \%$ respectivamente para la prueba de PCR y el $75 \%$ y el $75 \%$ para MRT. En conclusión, PCR es una herramienta muy útil para el diagnóstico rápido de $B$. melitensis en leche de oveja.
\end{abstract}

Key words: Brucella melitensis, sheep, milk, PCR.

Palabras clave: Brucella melitensis, oveja, leche, PCR.

\section{INTRODUCTION}

Brucellosis continues to be a problem for animal and humans throughout the world (Bricker 2002). The genus of Brucella comprises of Gram-negative, non-motile and facultative intracellular pathogens and six species are recognized within the genus: Brucella melitensis, $B$. abortus, B. ovis, B. canis, B. suis and B. neotomae (Moreno et al 2002, Rivers et al 2006). With respect to the current classification of Brucella species according to the preferential host, two new species have been recognized, $B$. pinnipediae (for pinniped isolates) and B. cetaceae (for cetacean isolates) (Cloeckaert et al 2001). B. melitensis causes an important infectious disease affecting mostly small ruminants and humans (Blasco et al 1994). The udder is an important predilection site for Brucella. In dairy animals, microorganisms localize in the supramammary lymph nodes and these can continue to excrete them in milk (Cordes and Carter 1979, Refai 2003). People contract the disease by direct contact with contaminated fetal membranes or, more commonly, as a result of the consumption of contaminated unpasteurized milk and cheese products (Young 1983, Wallach et al 1994). Studies

\footnotetext{
Accepted: 31.10.2007.

\# This study was funded by The Scientific \& Technological Research Council of Turkey (TUBİTAK) (Project numbers, TOVAG: 104V035 and TOVAG: 105O014).

* Faculty of Veterinary Science, Department of Microbiology, 65080 Van, Turkey; zilhan@yyu.edu.tr, ziyavan52@yahoo.com
}

performed in different regions of Turkey have shown that B. melitensis is responsible for approximately $20 \%$ of the abortion cases in sheep (Arda et al 1987, Kenar et al 1990). Thus, brucellosis is one of the major problems of the sheep industry in Turkey, and it could be estimated that the disease results in huge economic losses. Moreover, in the region of Van in East Anatolia in Turkey, humans often consume Herby Cheese (Otlu Peynir) produced from raw milk (Ekici et al 2006).

The methods for the diagnosis of brucellosis comprise tests for isolation and identification, tests for detection and estimation of antibodies induced in response to the agent, as well as an allergic test, brucellin, particularly in small ruminants (Refai 2003). Serologic methods are not conclusive, because not all infected animals produce detectable levels of antibodies and because cross-reactions with antigens other than those from Brucella can give false-positive results. However, milk ring test (MRT) is probably the most widely used test for screening and monitoring of brucellosis in dairy cattle (Alton et al 1988). The sensitivity of the bacteriological culture methods depends on the viability and numbers of Brucella in the sample, and the nature of the sample which is commonly contaminated with other bacteria. Thus, culture methods are not always successful as they are time-consuming and the handling of microorganism is hazardous (Refai 2003). PCR has the potential to meet the need for better diagnostic tools for several infectious diseases caused by fastidious or slow growing bacteria (Romero et al 1995, Bricker 2002). Although previous 
studies have demonstrated that PCR based assays can be used to detect Brucella DNA in pure cultures (Romero et al 1995, Rijpens et al 1996) and different samples of goats (Leal-Klevezas et al 1995, Leal-Klevezas et al 2000) and bovine (Romero and Lopez-Goñi 1999, O'Leary et al 2006), the brucellosis of the sheep has received comparatively little attention by using milk as material. The purpose of this study was to investigate the viability of the PCR assay as a diagnostic tool for the detection of $B$. melitensis DNA in the milk of sheep after abortion and to compare its results with traditional bacteriological culture methods and MRT.

\section{MATERIAL AND METHODS}

\section{SAMPLING, BACTERIOLOGICAL EXAMINATIONS AND MRT}

During 2 successive lambing seasons (in the years of 2004-2005, 2005-2006) 102 sheep milk samples after abortion in 92 different sheep flocks were collected in the Van region of Turkey. The total sheep number was 10.833 and 1.263 ewes aborted in these flocks. The materials used in this study were collected from animals that were not previously vaccinated against Brucella. All samples were taken approximately 1-3 days after abortion. Samples were collected under sterile hygienic conditions from both udders. Fifteen $\mathrm{ml}$ of the milk were sampled and subdivided into $5 \mathrm{ml}$ aliquots. These were used in culture, PCR and MRT. Samples destined for PCR assay were kept at $-20^{\circ} \mathrm{C}$ until processing.

Swabs from the fatty top layer and centrifugation pellet $\left(3,000 \mathrm{rpm}\right.$ for $15 \mathrm{~min}$ at $\left.4{ }^{\circ} \mathrm{C}\right)$ of raw milk was previously tested onto duplicate plates with blood agar (Merck, Darmstadt, Germany) containing 5\% defibrinated sheep blood, blood agar base № 2 (Oxoid, Hampshire, England) supplemented with Brucella selective supplement (Oxoid, SR083A) and 5\% defibrinated sheep blood. The defibrinated sheep blood was collected from Brucella-free sheep from the Research Farm of the Faculty of Veterinary Science, University of Yüzüncü Y1l. The samples were also plated onto Farrell's modified serum dextrose agar. The latter was prepared from blood agar base $\mathrm{N}^{\circ} 2$ supplemented with Brucella selective supplement (Oxoid, SR083A), 7\% horse serum and 1\% glucose (Stack et al 2002). All plates were incubated at $37{ }^{\circ} \mathrm{C}$, both in air and microaerobically (5-10\% $\mathrm{CO}_{2}$ ) for 5-7 days. Identification and typing of Brucella strains were performed using standard classification tests, including growth characteristics, catalase, oxidase and urease activity, $\mathrm{H}_{2} \mathrm{~S}$ production, growth in presence of thionin $(40 \mu \mathrm{g} / \mathrm{ml}, 20 \mu \mathrm{g} / \mathrm{ml}$ and $10 \mu \mathrm{g} / \mathrm{ml})$ and basic fuchsine $(20 \mu \mathrm{g} / \mathrm{ml}$ and $10 \mu \mathrm{g} / \mathrm{ml})$, lysis by Tbilisi (Tb) phage and agglutination with monospecific $\mathrm{A}$ and $\mathrm{M}$ antisera (Alton et al 1988, Quinn et al 1994). Identification of the other bacteria was performed by conventional biochemical tests (Quinn et al 1994). B. melitensis reference strain
$16 \mathrm{M}$, B. abortus reference strain S19 (for control of Tb phage) and Tb phage, which had been kept in the culture collection of the Department of Microbiology, Faculty of Veterinary Science, University of Yüzüncü Y1l, were supplied by the Pendik Veterinary Control and Research Institute, İstanbul, Turkey.

MRT

A modification of the procedure described by Alton et al (1988) was used in the MRT. MRT antigen prepared from B. abortus $\mathrm{S} 99$ strain and stained with tetrazolium chloride was supplied by the Pendik Veterinary Control and Research Institute, İstanbul, Turkey. The test was performed in sterile tubes and the milk samples were tested within $2 \mathrm{~h}$ after collection. Fresh milk samples from the individual sheep were thoroughly shaken and $1 \mathrm{ml}$ of the milk was transferred into to a fresh tube and $30 \mu 1$ of MRT antigen was added. The tubes were mixed thoroughly and incubated at $37^{\circ} \mathrm{C}$ for $3 \mathrm{~h}$. When the antigen precipitated in the bottom of tubes and/or the purple band occurred at the top of milk, these samples were then regarded as positive (Türütoğlu et al 2003).

\section{DNA EXTRACTION AND PCR}

B. melitensis DNA was extracted from milk by the method of Leal-Klevazas et al (2000). Briefly, frozen milk samples were thawed at room temperature and $400 \mu \mathrm{l}$ of lysis solution (100 mM Tris- $\mathrm{HCl}$ (pH 8), $100 \mathrm{mM} \mathrm{NaCl}$, $1 \%$ SDS, $2 \%$ Triton-X100) and $10 \mu \mathrm{l}$ of proteinase $\mathrm{K}$ $(10 \mathrm{mg} / \mathrm{ml})$ were added to $400 \mu \mathrm{l}$ of the fatty top layer of each milk sample. The contents were incubated at $50{ }^{\circ} \mathrm{C}$ for $30 \mathrm{~min}$. Thereafter, $400 \mu \mathrm{l}$ of saturated phenol (liquid phenol containing $0.1 \%$ 8-hydroxyquinoline, saturated and stabilized with $10 \mathrm{mM}$ Tris- $\mathrm{HCl}(\mathrm{pH} 8)$ and $0.2 \%$ of 2-mercaptoethanol) were added, mixed thoroughly and centrifuged at $8.000 \mathrm{x} \mathrm{g}$ for $5 \mathrm{~min}$. The aqueous layer was transferred to a fresh tube and an equal volume of chloroform:isoamyl alcohol (24:1) was added, mixed thoroughly and centrifugated as described above. The upper layer was again transferred to a fresh tube and an equal volume of $7.5 \mathrm{M}$ ammonium acetate was added and mixed thoroughly. The contents were kept on ice for $5 \mathrm{~min}$, centrifugated at $8,000 \times \mathrm{g}$ for $5 \mathrm{~min}$ and the aqueous content was transferred to a fresh tube. Two volumes of $95 \%$ ethanol were added, mixed and the tubes were stored at $-20{ }^{\circ} \mathrm{C}$ for $12 \mathrm{~h}$. DNA was recovered by the final centrifugation as described above, the pellets were rinsed with $1 \mathrm{ml}$ of $70 \%$ ethanol, dried and resuspended in $30 \mu \mathrm{l}$ TE buffer (AppliChem, Darmstadt, Germany). In addition, a commercial DNA extraction kit (Dneasy® Tissue Kit, Qiagen, Hilden, Germany) was also used in this study. For this purpose, $25 \mu \mathrm{g}$ of the fatty top layer were used as the initial extraction material. Subsequent extraction stages were applied according to the manufacturer's recommen- 
dations. Finally the DNA extraction was stored at $-20^{\circ} \mathrm{C}$ until they were processed in a thermal cycler.

\section{SYNTHETIC OLIGONUCLEOTIDE DESIGN}

The B. melitensis-specific primers used were previously described by Bricker and Halling (1994). The sequences of the primers were 5'-AAA, TCG, CGT, CCT, TGC, TGG, TCT, GA-3' (B. melitensis-specific primer) and 5'-TGC, CGA, TCA, CTT, AAG, GGC, CTT, CAT-3' (IS711-specific primer).

\section{DNA AMPLIFICATION AND DETECTION OF PCR PRODUCTS}

PCR was carried out in a total volume of $50 \mu \mathrm{l}$, using $10 \mathrm{mM}$ Tris- $\mathrm{HCl}$ (pH 9), $3 \mathrm{mM} \mathrm{MgCl}_{2}, 50 \mathrm{mM} \mathrm{KCl}, 0.1 \%$ Triton-X100, $200 \mathrm{mM}$ of the each four deoxynucleotide triphosphates (Lavora, Tellow, Germany), $0.4 \mathrm{mM}$ of each primer (50 pmol), 2 IU of Taq polymerase (Fermentas, Opelstrasse 9, Leon-Rot, Germany) and $2 \mu$ template. The amplification was performed in a DNA thermal cycler (Thermo, Px2 Thermal Cycler, USA) as follows: initial denaturation step at $94{ }^{\circ} \mathrm{C}$ for $4 \mathrm{~min}$, and 35 cycles of $94^{\circ} \mathrm{C}$ for $1 \mathrm{~min}, 60^{\circ} \mathrm{C}$ for $1 \mathrm{~min}$ and $72^{\circ} \mathrm{C}$ for $1 \mathrm{~min}$. The final incubation was at $72{ }^{\circ} \mathrm{C}$ for $5 \mathrm{~min}$ (Leal-Klevezas et al 2000).

Amplification products were resolved in a $1.5 \%(\mathrm{w} / \mathrm{v})$ agarose gel containing $1 \times \mathrm{TBE}$ buffer $(100 \mathrm{mM}$ Tris-HCl (pH 8), $90 \mathrm{mM}$ boric acid and $1 \mathrm{mM} \mathrm{Na} \mathrm{N}_{2}$ EDTA) and stained with ethidium bromide $(0.5 \mu \mathrm{g} / \mathrm{ml})$ and evaluated by a computerized image analysis system (Spectronics Co., Gl-5000, England). A visible band of appropriate size (731 bp) was considered as a positive reaction for B. melitensis. A positive control (based on DNA from B. melitensis $16 \mathrm{M}$ ) and a negative control (DNases and RNases free water, AppliChem) were included in all the tests. To check the reliability of the results and to detect any external contamination, all samples were processed in duplicate.

\section{DETERMINATION OF DETECTION LIMIT OF THE PCR IN} INOCULATED MILK

B. melitensis $16 \mathrm{M}$ strain was grown on trypticase soy agar (TSA, Merck) at $37{ }^{\circ} \mathrm{C}$ for $48 \mathrm{~h}$. A single colony was removed from TSA, placed in trypticase soy broth (Merck) and incubated at $37^{\circ} \mathrm{C}$ for $48 \mathrm{~h}$. Thereafter, the culture was prepared in sterile saline and 10-fold dilutions (from $10^{-1}$ to $10^{-10}$ ) were made. From these dilutions, $0.1 \mathrm{ml}$ suspension was inoculated onto TSA plates and incubated at $37{ }^{\circ} \mathrm{C}$ for $48 \mathrm{~h}$ and the colonies present were then enumerated. The number of organisms in the dilutions was estimated spectro-photometrically at $623 \mathrm{~nm}$ and the concentration of the original B. melitensis culture was estimated as 1.7 x $10^{9} \mathrm{cfu} / \mathrm{ml}$ (OD 0.18). To assess the limit of detection of the PCR assays, 12 raw milk samples collected from
Brucella-free sheep from the Research Farm of Faculty of Veterinary Science, University of Yüzüncü Y1l, were artificially contaminated with a known decreasing number of pure $B$. melitensis $16 \mathrm{M}$ strain. The final concentrations of the organism in milk was $1.7 \times 10^{8}, 1.7 \times 10^{7}, 1.7 \times 10^{6}$, $1.7 \times 10^{5}, 1.7 \times 10^{4}, 1.7 \times 10^{3}, 1.7 \times 10^{2}$ and $1.7 \times 10^{1} \mathrm{cfu} /$ $\mathrm{ml}$. B. melitensis DNA was extracted from all dilutions of milk, and processed by PCR as described earlier. The final concentrations of organisms were verified by plating onto TSA.

\section{STATISTICAL ANALYSIS}

PCR assay and MRT results were analyzed by comparison of two proportions method (Armitage 1977). In the present study, to calculate diagnostic sensitivity and specificity of the PCR and MRT, 8 milk samples from which $B$. melitensis was isolated were accepted as true positives. The sensitivity and specificity were calculated as described previously (Thrusfield 1986).

\section{RESULTS}

COMPARISON OF PCR WITH BACTERIOLOGICAL CULTURE AND MRT

A total number of $8(7.8 \%)$ Brucella positive samples were detected only in Farrell's modified serum dextrose agar of the 102 milk samples. All Brucella organisms were identified and biotyped as B. melitensis biovar 3 by tests; positive catalase, oxidase and urease, reduced nitrate, negative $\mathrm{H}_{2} \mathrm{~S}$, no $\mathrm{CO}_{2}$ requirement, no lysis by $\mathrm{Tb}$ phage, growth in the presence of thionin and basic fuchsin and positive agglutination with monospecific $\mathrm{A}$ and $\mathrm{M}$ antisera. $B$. ovis and the other Brucella species were not isolated in the remaining $94(92.1 \%)$ milk samples in this study (table 1). In culture, 21 milk samples were positive for Staphylococcus spp. (hemolytic activity on 5\% sheep blood agar, colony and microscopic morphology, positive catalase and negative oxidase tests), 14 for Streptococcus spp. (hemolytic activity on 5\% sheep blood agar, colony and microscopic morphology and negative catalase test), 12 for E. coli (positive indole production, methyl red, lactose, maltose, mannitol, mannose and xylose fermentation activities, negative oxidase, Voges-Proscauer, urease and hydrogen sulphide tests), 8 for $S$. aureus (goldenyellow pigment and hemolytic activity on 5\% sheep blood agar, positive catalase, coagulase (with rabbit plasma), DNase, mannitol and maltose fermented tests) and 5 for Corynebacterium spp. (colony and microscopic morphology, positive or negative catalase, urease, nitrat reductase tests and aesculin hydrolysis). In 24 (23.5\%) of the milk samples, PCR products with a molecular size of $731 \mathrm{bp}$ indicative of $B$. melitensis DNA were obtained. Of the 102 milk samples, 28 (27.4\%) tested positive by MRT. When culture and PCR results were compared, 8 samples tested 
positive and 78 samples tested negative with both methods. All the milk samples that tested positive by culture also tested positive by PCR (table 1). When PCR and MRT results were compared, 22 samples tested positive and 72 negative with both assays. The agreement between PCR and MRT was determined as $96 \%$. When the results of PCR and MRT were compared with the bacterial culture results, the diagnostic sensitivity and specificity were determined as $100 \%$ and $81.3 \%$ respectively for PCR assay and $75 \%$ and $75 \%$ for MRT. Table 1 shows the results of bacteriological isolation, PCR assay and MRT.

Table 1. Bacteriological culture, $P C R$ assay and MRT results of 102 milk samples taken from sheep after abortion.

Cultivo bacteriológico, prueba PCR y resultados MRT de 102 muestras de leche tomadas de ovejas postaborto.

\begin{tabular}{cccccccc}
\hline & \multicolumn{2}{c}{ Bacteriological culture } & $\begin{array}{c}\text { PCR } \\
\text { assay }{ }^{\mathrm{a}}\end{array}$ & MRT $^{\mathrm{b}}$ \\
\hline & Milk (n=102) & & $\begin{array}{c}\text { Milk } \\
(\mathrm{n}=102)\end{array}$ & $\begin{array}{c}\text { Milk } \\
(\mathrm{n}=102)\end{array}$ \\
\hline Blood Agar & $\begin{array}{c}\text { Blood Agar } \\
\text { Base No:2 }\end{array}$ & Farrell's Agar & + & - & + & - \\
0 & 0 & $+(\mathrm{n}=8)^{\mathrm{c}}$ & 8 & 0 & 6 & 2 \\
0 & 0 & $-(\mathrm{n}=94)$ & 16 & 78 & 22 & 72 \\
0 & 0 & 8 & 24 & 78 & 28 & 74 \\
\hline
\end{tabular}

a Polymerase chain reaction assay, ${ }^{\mathrm{b}}$ Milk ring test, ${ }^{\mathrm{c}}$ All Brucella strains were typed as $B$. melitensis biovar 3 .

\section{DETECTION LIMIT OF THE PCR}

A positive PCR result on the ethidium bromide stained agarose gel was detected with different aliquots containing B. melitensis at a density of at least $1.7 \times 10^{3}-1.7 \times 10^{4}$ $\mathrm{cfu} / \mathrm{ml}$ in milk (figure 1).

\section{DISCUSSION}

Brucella are fastidious and relatively slow growing organisms (Stack et al 2002). There are many selective media for the primary isolation of Brucella from grossly contaminated clinical materials, such as milk samples (Leal-Klevezas et al 1995, Hamdy and Amin 2002). In this study, Brucella was not isolated from milk samples cultured on blood agar and blood base $\mathrm{N}^{\circ} 2$. However, the microorganism was isolated in 8 out of 102 milk samples using Farrell's modified serum dextrose agar. We suggest that this selective agar is an appropriate medium for the primary isolation of B. melitensis in the milk samples of sheep.

In this study, $8(7.8 \%)$ Brucella strains were determined as B. melitensis biovar 3. This is the first report regarding the typing of Brucella strains isolated from sheep milk in the region of Van, in East Anatolia, Turkey. This finding

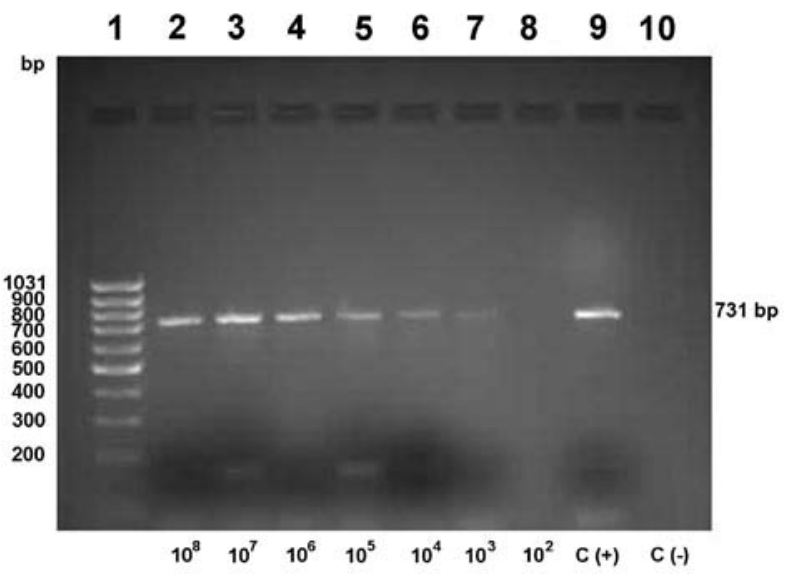

Figure 1. Detection limit of B. melitensis $16 \mathrm{M}$ strain in inoculated milk by PCR assay. Line 1: Marker (GeneRuler 100bp DNA Ladder, Fermentas); Lines 2-8: containing decreasing number of $B$. melitensis $16 \mathrm{M}$ per $\mathrm{ml}$ of milk. Line $2: 1.7 \times 10^{8}$; Line 3: $1.7 \times 10^{7}$; Line $4: 1.7 \times 10^{6}$; Line $5: 1.7 \times 10^{5}$; Line $6: 1.7 \times 10^{4}$; Line 7: $1.7 \times 10^{3} ;$ Line $8: 1.7 \times 10^{2} \mathrm{cfu} / \mathrm{ml}$; Line 9: control positive (based on DNA from B. melitensis $16 \mathrm{M}$ strain); Line 10: control negative (DNases and RNases free water, AppliChem).

Límite de detección de la cepa $B$. melitensis $16 \mathrm{M}$ inoculada en leche, mediante la prueba de PCR. Línea 1: Marcador (Escalera de GeneRuler 100bp DNA, Fermentas); Línea 2-8: Contenido decreciente de B. melitensis $16 \mathrm{M}$ por $\mathrm{ml}$ de leche. Líneas $2: 1,7 \times 10^{8}$; Línea 3: 1,7 $\times 10^{7}$;

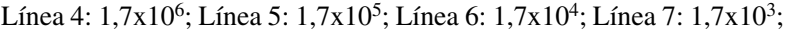

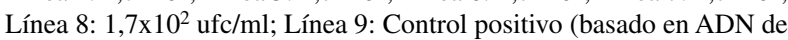
la cepa B. melitensis $16 \mathrm{M}$ ); Línea 10: Control negativo (Agua libre de Dnases y Rnases, AppliChem).

suggests that $B$. melitensis biovar 3 is the predominant strain isolated in the milk of sheep after abortion in East Anatolia. This finding is in accordance with the results of Erdenliğ and Șen (2000) who informed that of 78 Brucella strains from different regions of Turkey, $88.5 \%$ were of B. melitensis biovar 3. In another report from Turkey, 39 Brucella isolates from sheep materials in Central Anatolia in Turkey, $94.8 \%$ were also of B. melitensis biovar 3 (Güler et al 2003).

Bacteriological isolation of Brucella and its identification has been described as the "gold-standard", the most reliable diagnosis of brucellosis (Alton et al 1975). In this study, 8 milk samples from which $B$. melitensis biovar 3 was isolated were accepted as true positive. The diagnostic sensitivity of the PCR was extreme (100\%) compared with MRT (75\%). The diagnostic specificity was determined as $81.3 \%$ for PCR and $75 \%$ for MRT. Since so little data is available for milk-PCR and MRT, the results of sensitivity and specificity obtained from this study could not be discussed.

B. melitensis species-specific primers were used in this research since previous studies in the Van region (Gürtürk et al 1995) and in other regions of Turkey (Arda et al 1987, Kenar et al 1990, Güler et al 2003) indicated that only $B$. melitensis strains were isolated from aborting ewes and in none of them were isolated B. ovis strains. 
It has been reported that the detection limit of the PCR in milk samples range from 10 bacteria/ml (LealKlevezas et al 1995), $1000 \mathrm{cfu} / \mathrm{ml}$ (Hamdy and Amin 2002), $2.8 \times 10^{4} \mathrm{cfu} / \mathrm{ml}$ (Rijpens et al 1996) to $4.2 \times 10^{4}$ $\mathrm{cfu} / \mathrm{ml}$ (Romero and Lopez-Goñi 1999). In this research, $1.7 \times 10^{3}-1.7 \times 10^{4} \mathrm{cfu} / \mathrm{ml}$ of $B$. melitensis $16 \mathrm{M}$ strain were detected by PCR. These results suggest that the sensitivity of PCR was affected by extraction procedures. The extraction procedure applied in this research has been shown to be successful in the detection of $B$. melitensis DNA in the milk of sheep after abortion (Leal-Klevezas et al 2000).

A veterinary diagnostic tool using PCR-based assays has been applied to bovine milk (Leal-Klevezas et al 1995, Romero and Lopez-Goñi 1999, O'Leary et al 2006) and caprine milk (Leal-Klevezas et al 1995, Leal-Klevezas et al 2000). However, insufficient data are available to evaluate the performance of the assays for the detection of Brucella DNA from ovine milk samples. In a study by Hamdy and Amin (2002), 103 milk samples were collected from 52 cows, 21 ewes, 18 goats and 12 camels. The milk samples were tested by culture, PCR and MRT. The PCR assay amplified Brucella DNA from 53 milk samples and the direct culture method detected Brucella organisms from 47 samples. 73 milk samples were evaluated as positive by MRT. In agreement with our results (102 samples, 24/8), Leal-Klevezas et al (2000) also detected as positive a higher number of milk samples by PCR assay when compared to bacteriological culture methods (17 samples, 11/0). This was probably because Brucella was present in very low numbers, which would be consistent with the small number of colony forming units detected in milk samples by culture methods (O'Leary et al 2006). In the present study, the agreement between PCR and MRT was $96 \%$ and when the results of PCR and MRT were compared, a higher number of samples were evaluated as positive by MRT than PCR assay (28/24) and this is partially similar to the results (103/73) of Hamdy and Amin (2002). MRT is the most widely used test for monitoring and screening brucellosis in dairy cattle (Alton et al 1988). In this study, a high positive result with MRT could be due to a lack of specificity of the test for the diagnosis of brucellosis in sheep milk (Alton et al 1988) or various milk conditions such as mastitis, colostrum and milk at the end of the lactating cycle (OIE Manual 2000). Another reason lies in the underlying principle of these assays, the MRT detects a serological response whereas both the PCR and culture detect the organism itself. Therefore, the animal must be shedding the bacteria in the milk in order to detect them by these methods. Moreover, serological tests give false-positive results due to cross-reactions with other bacteria including Yersinia enterocolitica O:9, Campylobacter fetus, Vibrio cholera, Bordetella bronchiseptica and Salmonella species (Alton et al 1988, Quinn et al 1994).
The PCR results achieved in this study are in agreement with the results obtained in previous studies, i.e. less variable than the results of bacteriology or serology (Leal-Klevezas et al 1995, Leal-Klevezas et al 2000, Hamdy and Amin 2002). Deficient isolation techniques or the stage of infection may explain the superiority of the PCR assay to isolation methods. Moreover, PCR assay detects both living and dead organisms, while bacteriological culture methods detect only living organisms.

The specificity of the primers used in the current study has been evaluated with a variety of microorganisms that have a close antigenic relationship with Brucella which causes false-positive results in serology, and the absence of amplification with DNA of these species has shown the primers to be specific for B. melitensis biovars 1, 2 and 3 (Bricker and Halling 1994).

The determination of B. melitensis from sheep milk samples is important in production of Herby Cheese (Otlu Peynir), one of the popular cheeses traditionally produced from raw milk of sheep, goat and cow or a mixture of these in eastern Turkey, including the Van region (Ekici et al 2006). Thus, Herby Cheese may be a route for transmission of brucellosis to humans. Therefore, control of the brucellosis in animals should lead to decreased incidence of the disease in humans.

In this study, B. melitensis DNA was detected in 24 (23.5\%) out of 102 milk samples by PCR, while only 8 (7.8\%) samples positive by bacteriological isolation methods. This indicated that the sensitivity of the PCR assay was higher than that of the culture method. The results achieved in this study are in agreement with the data obtained in previous works (Leal-Klevezas et al 1995, Romero et al 1995, Hamdy and Amin 2002). The described PCR has several advantages over the bacteriological culture methods, since the PCR is more rapid and sensitive than bacteriological culture methods and the amount of milk used for assay is much more smaller than that required for culture methods. In conclusion, PCR assay is a very useful tool for the rapid diagnosis of $B$. melitensis in sheep milk.

\section{SUMMARY}

Laboratory diagnosis of brucellosis is generally performed by microbiological and serological methods. PCR assay is a specific and sensitive choice for the detection of different bacterial agents. An evaluation of this test was carried out for the detection of Brucella melitensis DNA in sheep milk. 102 milk samples from sheep after abortion were taken and studied using bacteriological culture, PCR and milk ring test (MRT). PCR found B. melitensis DNA in 24 (23.5\%) out of 102 milk samples, while only $8(7.8 \%)$ of the samples were positive to $B$. melitensis through direct culture. MRT found 28 (27.4\%) positive milk samples. The detection limit for PCR in sheep milk inoculated with $B$. melitensis strain $16 \mathrm{M}$ was $1.7 \times 10^{3}-1.7 \times 10^{4} \mathrm{cfu} / \mathrm{ml}$. PCR and MRT coincidence was $96 \%$. The diagnostic sensitivity and specificity were determined as $100 \%$ and $81.3 \%$ respectively for PCR assay and $75 \%$ and $75 \%$ for MRT. PCR is a useful tool for a fast diagnosis of $B$. melitensis in sheep milk. 


\section{ACKNOWLEDGEMENTS}

This study is part of project funded by The Scientific \& Technological Research Council of Turkey (TUBITAK) (Project numbers, TOVAG: 104V035 and TOVAG: 105O014). We would like to thank Dr. S. Erdenliğ from Pendik Veterinary Control and Research Institute for her contribution in the typing of B. melitensis strains. We also thank Vet. Med. F. Aslantosun and Vet. Med. Ș. Ertaș for their help with the collection of samples.

\section{REFERENCES}

Alton GG, LM Jones, DE Pietz. 1975. Laboratory techniques in brucellosis. WHO Monograph Series № 55, Geneva, Switzerland, Pp 1-163.

Alton GG, LM Jones, RD Angus, JM Verger. 1988. Techniques for the brucellosis laboratory. Institute National de la Recherche Agronomique, Paris, France, Pp 13-61.

Arda M, W Bisping, N Aydın, E İstanbulluoğlu, Ö Akay, M İzgur, S Diker, Z Karaer. 1987. An etiologic and serologic investigations of ovine abortion in Central Anatolia Region. Vet J Ankara Univ 34, 195-206.

Armitage P. 1977. Statistical methods in medical research. Blackwell Publications, Great Britain, Pp 126-131.

Blasco JM, C Marin, M Jimenez de Bagues, M Barberan, A Hernandez, L Molino, J Velasco, R Diaz, I Moriyon. 1994. Evaluation of allergic and serological test for diagnosing Brucella melitensis infection in sheep. J Clin Microbiol 32, 1835-1840.

Bricker BJ, SM Halling. 1994. Differentiation of Brucella abortus bv. 1, 2 and 4, Brucella melitensis, Brucella ovis and Brucella suis bv. 1 by PCR. J Clin Microbiol 32, 2660-2666.

Bricker BJ. 2002. PCR as a diagnostic tool for brucellosis. Vet Microbiol 90, 435-446.

Cloeckaert A, JM Verger, M Grayon, JY Paquet, B Garin-Bastuji, G Foster, J Godfroid. 2001. Classification of Brucella spp. isolated from marine mammals by DNA polymorphism at the omp2 locus. Microbes Infect 3, 729-738.

Cordes DO, ME Carter. 1979. Persistency of Brucella abortus infection in six herds of cattle under brucellosis eradication. New Zealand Vet $J$ 27, 255-259.

Ekici K, H Coșun, Z Tarakçı E. Öndül, Șekeroğlu. 2006. The contribution of herbs to the accumulation of histamine in otlu cheese. J Food Biochem 30, 362-371.

Erdenliğ S, A Șen. 2000. Isolation and biotyping of Brucella species from aborted ewes fetuses. The Journal of Pendik Veterinary Microbiology 31, 31-42.

Güler L, K Gündüz, Ü Ok. 2003. Comparison of polymerase chain reaction and bacteriological culture for the diagnosis of sheep brucellosis using aborted fetus samples. Vet Microbiol 93, 53-61.

Gürtürk K, A Aksakal, B Baydaș. 1995. Etiological and serological examinations on brucellosis in aborted sheep in Van region. Journal of Health Sciences of Yüzüncü Yll University 2, 13-15.
Hamdy MER, AS Amin. 2002. Detection of Brucella species in the milk of infected cattle, sheep, goats and camels by PCR. Vet $J$ 163, 299-305.

Kenar B, O Erganis, O Kaya, E Güler. 1990. Bacteriological and serological survey on Brucella, Campylobacter, Salmonella and Chlamydia infections caused to sheep abortion in Konya region (Central Anatolia) in Turkey. Veterinarium 1, 17-20.

Leal-Klevezas DS, IO Martinez-Vazquez, A López-Merino, JP MartinezSoriano. 1995. Single-step PCR for detection of Brucella spp. from blood and milk of infected animals. J Clin Microbiol 33, 3087-3090.

Leal-Klevezas DS, IO Martinez-Vazquez, J Garcia-Cantu, A LopezMerino, JP Martinez-Soriano. 2000. Use of polymerase chain reaction to detect Brucella abortus biovar 1 in infected goats. Vet Microbiol 75, 91-97.

Moreno E, A Cloeckaert, I Moriyon. 2002. Brucella evaluation and taxonomy. Vet Microbiol 90, 209-227.

OIE, World organization for animal health. 2000. Manual of standards for diagnostic test and vaccine. Paris, Pp 328-345.

O'Leary S, M Sheahan, T Sweeney. 2006. Brucella abortus detection by PCR assay in blood, milk and lymph tissue of serologically positive cows. Res Vet Sci 81, 170-176.

Quinn PJ, ME Carter, BK Markey, GR Carter. 1994. Clinical veterinary microbiology. Wolfe Publishing, Spain, Pp 261-267.

Refai M. 2003. Application of biotechnology in the diagnosis and control of brucellosis in the Near East Region. World J Microbiol Biotechnol 19, 443-449.

Rijpens NP, G Jonnes, M Van Asbroeck, R Rossau, LMF Herman. 1996. Direct detection of Brucella spp. in raw milk by PCR and reverse hybridization with 16S-23S rRNA spacer probes. Appl Environ Microbiol 62, 1683-1688.

Rivers R, E Andrews, A Gonzalez-Smith, G Donoso, A Oñate. 2006. Brucella abortus: inmunidad, vacunas y estrategias de prevención basadas en ácidos nucleicos. Arch Med Vet 38, 7-18.

Romero C, C Gamazo, M Pardo, I Lopez-Goñi. 1995. Specific detection of Brucella DNA by PCR. J Clin Microbiol 33, 615-617.

Romero C, I Lopez-Goñi. 1999. Improved method for purification of bacterial DNA from bovine milk for detection of Brucella spp. by PCR. Appl Environ Microbiol 65, 3735-3737.

Stack JA, M Harrison, LL Perrett. 2002. Evaluation of a selective medium for Brucella isolation using natamycin. J Applied Microbiol 92, 724-728.

Thrusfield M. 1986. Veterinary epidemiology. Butterworth Co., London, UK, Pp 175-185.

Türütoğlu H, B Mutluer, Y Uysal. 2003. Investigation of Brucella infection in milk collected from Burdur province. Turk J Vet Anim Sci 27, 1003-1009.

Wallach JC, SE Mignel, PC Baldi, FA Guernera, FA Goldbaum, CA Fossati. 1994. Urban outbreak of a Brucella melitensis infection in an Argentine family: clinical and diagnostic aspects. FEMS Immunol Med Microbiol 8, 49-56.

Young EJ. 1983. Human brucellosis. Rev Infec Dis 5, 821-842. 